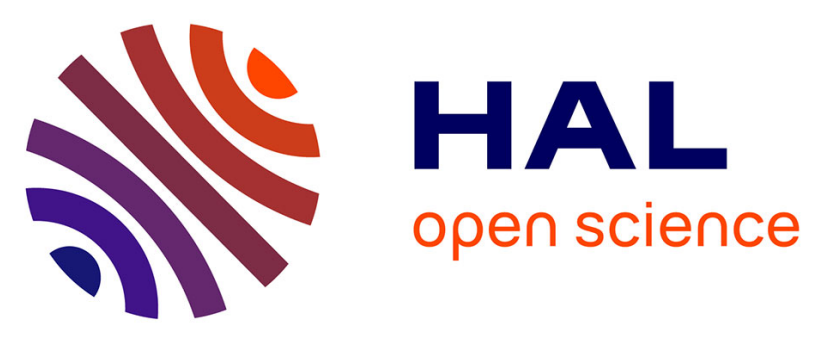

\title{
A Unified Strategy Toward 5-, 6-, and 7-Membered Nitrogen Heterocycles Through Free Radical then Metal-Mediated Functionalization of Ene-carbamates
}

Rédouane Beniazza, Clément Poittevin, Jonathan Lusseau, Stéphane Massip, Frédéric Robert, Yannick Landais

\section{- To cite this version:}

Rédouane Beniazza, Clément Poittevin, Jonathan Lusseau, Stéphane Massip, Frédéric Robert, et al.. A Unified Strategy Toward 5-, 6-, and 7-Membered Nitrogen Heterocycles Through Free Radical then Metal-Mediated Functionalization of Ene-carbamates. Advanced Synthesis and Catalysis, 2017, 359 (18), pp.3217-3225. 10.1002/adsc.201700485 . hal-03104344

\section{HAL Id: hal-03104344 https://hal.science/hal-03104344}

Submitted on 8 Jan 2021

HAL is a multi-disciplinary open access archive for the deposit and dissemination of scientific research documents, whether they are published or not. The documents may come from teaching and research institutions in France or abroad, or from public or private research centers.
L'archive ouverte pluridisciplinaire HAL, est destinée au dépôt et à la diffusion de documents scientifiques de niveau recherche, publiés ou non, émanant des établissements d'enseignement et de recherche français ou étrangers, des laboratoires publics ou privés. 


\title{
A Unified Strategy Toward 5-, 6-, and 7-Membered Nitrogen Heterocycles Through Free Radical then Metal-Mediated Functionalization of Ene-carbamates.
}

\author{
Redouane Beniazza, ${ }^{\text {a }}$ Clément Poittevin, ${ }^{\text {a }}$ Jonathan Lusseau, ${ }^{a}$ Stéphane Massip, ${ }^{b}$ \\ Frédéric Robert, ${ }^{a}$ and Yannick Landais ${ }^{a *}$ \\ a Institute of Molecular Sciences, UMR-CNRS 5255, University of Bordeaux, 351, Cours de la libération, \\ 33405 Talence cedex, France. e-mail: y.landais@ism.u-bordeaux1.fr \\ b Institut Européen de Chimie et Biologie, 2, Rue Robert Escarpit - 33607 Pessac, France
}

\begin{abstract}
Free-radical carbo-alkenylation of N-aryl, N-benzyl, and N-phenethyl-ene-carbamates with a disulfone provides vinylsulfones which may then be functionalized and engaged in Heck-type coupling to furnish highly substituted 5-, 6- and 7-membered nitrogen heterocycles. Grignardmediated cyclization starting from the same substrates further allowed a nucleophilic cascade process, affording a straightforward access to hydrocarbazoles, which may be regarded as potent intermediates for the synthesis of alkaloids of the aspidosperma family.
\end{abstract}

Keywords: Heterocycle; Heck reaction; Grignard; Vinylsulfones; Cyclization

\section{Introduction}

Nitrogen-containing heterocycles are widely distributed in nature and among biologically relevant targets. ${ }^{[1]}$ Because of their importance to pharmaceutical and agrochemical industries, ${ }^{[2]}$ organic chemists have explored numerous strategies to access them in a straightforward manner. ${ }^{[3]}$ Transitionmetal catalyzed processes ${ }^{[4]}$ (Heck coupling, ring-closing metathesis, ....), ionic cyclizations ${ }^{[5]}$ (halonium-mediated ring closure,....) or free-radical cyclizations ${ }^{[6]}$ hold a prominent place in this context, allowing a straightforward access to heterocycles of various ring size, from simple precursors under mild conditions. Despite the numerous methods reported to date, there is still a need for more straightforward methodologies to elaborate nitrogen heterocycles, allowing a fine tuning of the ring size, the installation of several stereogenic centers and a good compatibility with resident functional groups. Finally, unified strategies offering an access to heterocycles with various ring sizes are attractive, leading, through a minor modification of a common framework, to structures as diverse as those found in alkaloids depicted in Figure 1. ${ }^{[7]}$

In the course of our ongoing studies on free-radical processes, we have developed several carbofunctionalization of olefins, ${ }^{[8]}$ affording polyfunctional systems, which we anticipated, could be useful precursors in the preparation of nitrogen heterocycles, intermediates in the synthesis of more complex targets (Figure 1). 


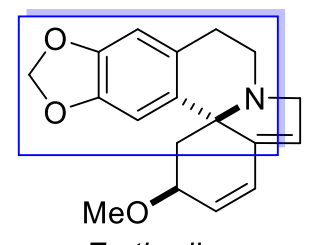

Erythraline

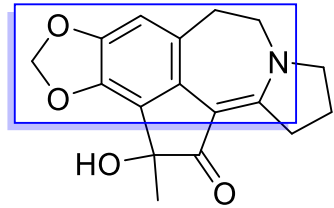

Hainanensine

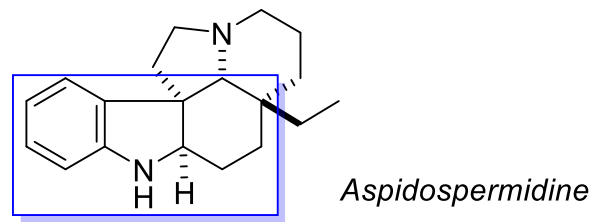

Figure 1. Nitrogen heterocycle formation

For instance, we showed that the carbo-alkenylation of electron-rich olefins leads to the formation of two new carbon-carbon bonds with the installation of two new functional groups. ${ }^{[8 b, c, g]}$ Ketones, esters, amides, thioesters are amongst the functional groups that may be added, starting from the corresponding xanthates or iodides. ${ }^{[8]}$ The second component is an olefin issued from a vinylsulfone (i.e. 3). A broad variety of addition adduct is thus available, changing the nature of the radical precursor and that of the sulfonyl trap. The free-radical carbo-alkenylation process is particularly efficient with electron-rich olefins as this radical chain is governed by polar effects. Ene-carbamate and enamides are thus excellent olefinic partners for this reaction and provide the addition products with generally high yields (Scheme 1).<smiles>CCOC(=O)CC(=O)OCC</smiles>

2a

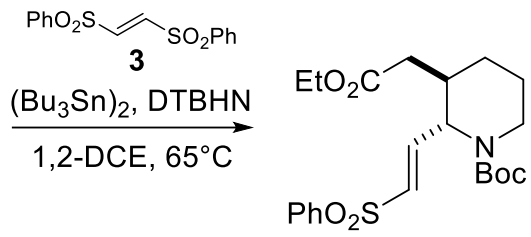

4a, $80 \%$ d.r. $>95: 5$
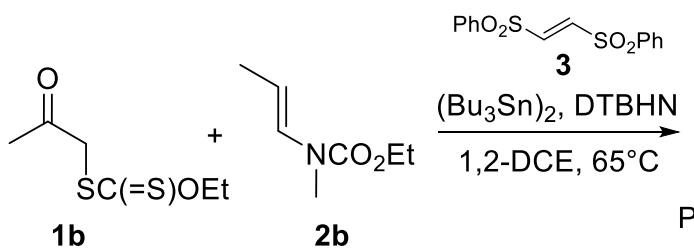

4b, $80 \%$ d.r. $1: 1$

Scheme 1. Carbo-alkenylation of ene-carbamates.

The occurrence of a nitrogen center and a nearby unsaturation in compounds 4a-b led us envisaged their further elaboration to access 5-, 6- and 7-membered heterocycles in a limited number of steps. Scheme 2 depicts a general strategy to access these medium-size heterocycles, starting from a common structural motif I, resulting from the carbo-alkenylation of ene-carbamates bearing an $\mathrm{N}$-alkylaryl moiety. The $\mathrm{C}-\mathrm{C}$ bond formation and ring-closure of these precursors would then be carried out relying on two organometallic processes, i.e. an intramolecular Heck reaction and a conjugate addition of a Grignard reagent. Depending on the position of the olefinic appendage and the length of the carbon chain between $\mathrm{N}$ and the aryl moiety, various heterocycles would thus be accessible. 


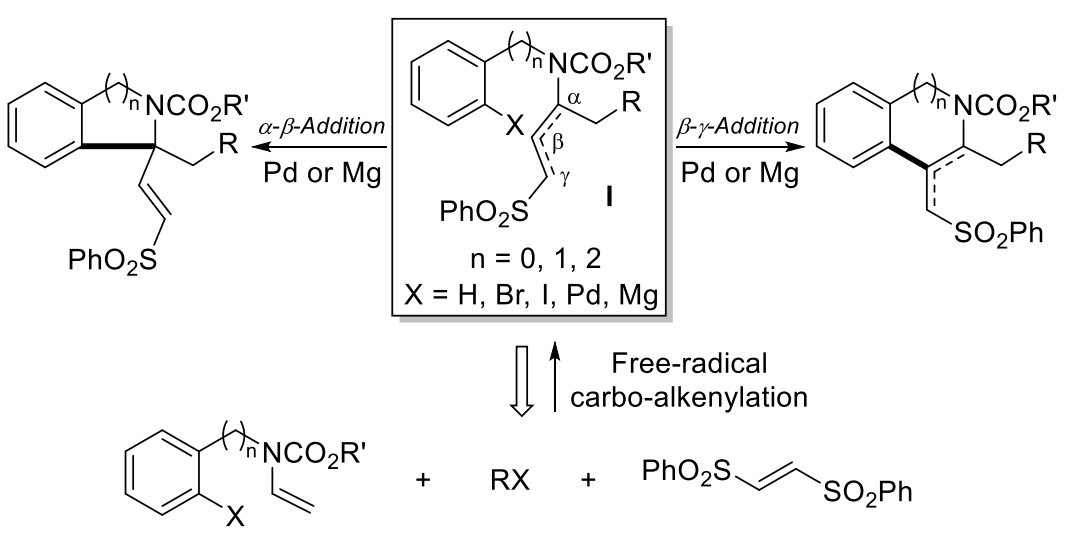

Scheme 2. A general strategy to access nitrogenated 5-, 6- and 7-membered heterocycles.

We report here our efforts to generate, from 3-component carbo-alkenylation products, 5-, 6- and 7membered heterocycles through the intramolecular addition of an aryl-metal species $(\mathrm{X}=\mathrm{Pd}$ or $\mathrm{Mg}$, Scheme 2) onto the unsaturated sulfone. Tandem nucleophilic cyclizations were also carried out on the same substrates, leading to polycyclic systems with good stereocontrol.

\section{Results and Discussion}

The study started with the preparation of the desired three-component adducts through the free-radical carbo-alkenylation of enamides 6a-g, using xanthates 5a-c and vinyldisulfone $\mathbf{3}$ under conditions reported previously. ${ }^{[8 \mathrm{~g}]}$ Conjugated sulfones $\mathbf{7 a - j}$ were thus obtained in generally high yields as the $E$ isomer (Table 1). Interestingly, the reaction conditions were compatible with substrates bearing a bromine substituent on the aromatic ring, as in $\mathbf{7 f}$ and $\mathbf{7 j}$. Finally, scaling up is allowed as $\mathbf{7 b}$ was for instance prepared on a $6.7 \mathrm{mmol}$ scale leading to $3.4 \mathrm{~g}$ of product.

Table 1. Free-radical carbo-olefination of enamides.

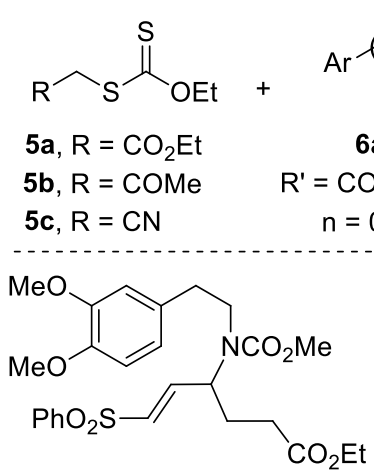

$7 a, 88 \%$<smiles>COc1ccc(CN(C(=O)O)C(=O)Oc2ccccc2)cc1OC</smiles>

7d, $88 \%$<smiles>COc1ccc(N(C(=O)OCc2ccccc2)C(/C=C/S(=O)(=O)c2ccccc2)CCC#N)cc1OC</smiles>

$7 g, 91 \%$

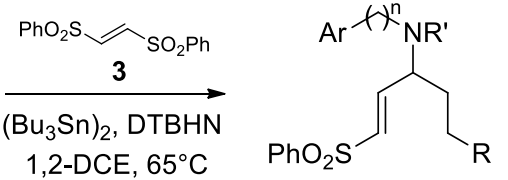

7a-j

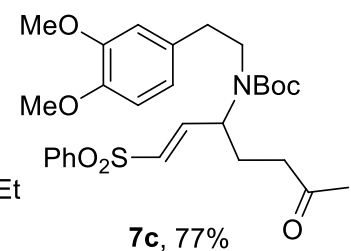

7b, $90 \%$

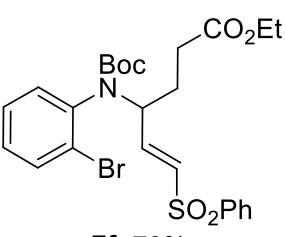

7f, $78 \%$<smiles>CCOC(=O)CCC(/C=C/S(=O)(=O)c1ccccc1)N(Cc1ccc(OC)c(OC)c1)C(=O)O</smiles>

7 e, $90 \%$<smiles>[R7]CCC(/C=C/S(=O)(=O)c1ccccc1)N(C(=O)OC)c1cc(OC)c(OC)c(OC)c1</smiles>

$7 \mathrm{~h}, \mathrm{R} "=\mathrm{CN} 83 \%$

$7 \mathrm{i}, \mathrm{R} "=\mathrm{CO}_{2}$ Et $90 \%$<smiles>CCOCCC(/C=C\Sc1ccccc1)Cc1ccccc1Br</smiles>

$7 j, 53 \%$ 
Iodination of the aryl substituent in $\mathbf{7 b}$-i was then carried out using $\mathrm{I}_{2}$ and $\mathrm{Ag}_{2} \mathrm{SO}_{4}$ in $\mathrm{MeOH}$. ${ }^{[9]}$ Iodoarenes 8a-c and 8e-f were obtained in good yields and excellent regioselectivity, except for arylamine $\mathbf{7 g}$, which led to an inseparable mixture of two ortho-iodoarenes 8d-d' in a $68 \%$ overall yield (Table 2).

Table 2. Iodination of arylamines $\mathbf{7 b - i}$.

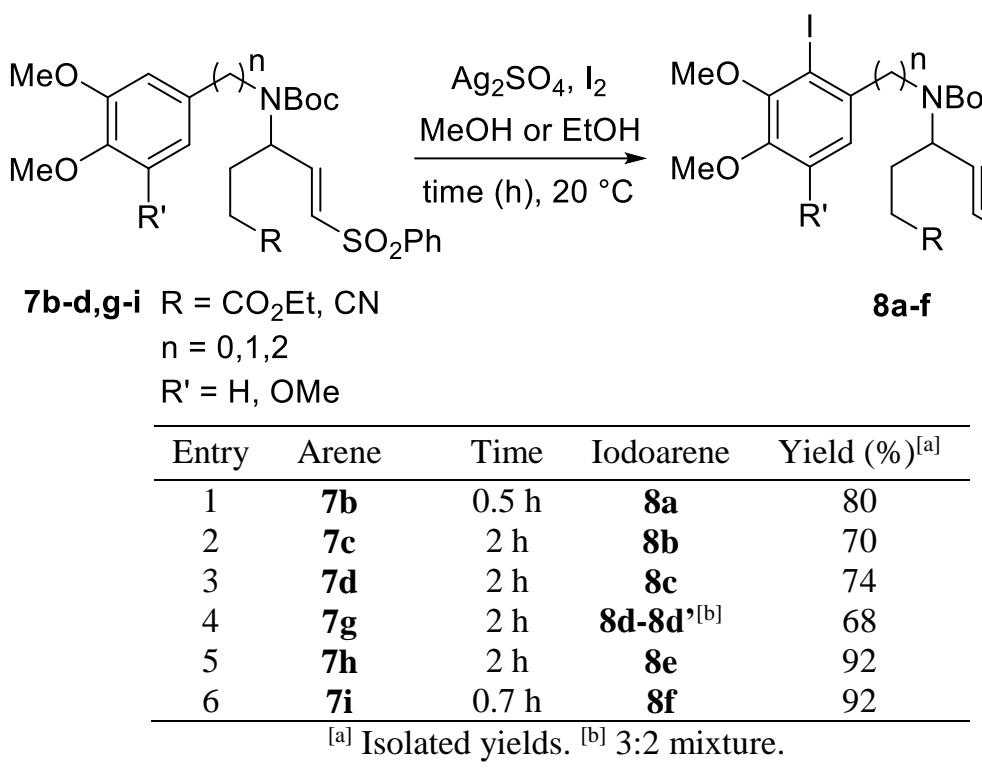

With the iodoarenes 8a-f in hands, we then evaluated their reactivity in Heck-type processes. ${ }^{[10]}$ Preliminary attempts were carried out using precursor $\mathbf{8 a}$, using $\mathrm{Pd}(\mathrm{OAc})_{2}$ and $\mathrm{PPh}_{3}$ with $\mathrm{DBU}$ as a base (Table 3, Conditions A, entry 1). ${ }^{[11]}$ Under these conditions, the expected 7-membered ring compound was not formed, but instead we observed the isomerization of the double bond to afford ene-carbamate 10. Changing the palladium source to $\operatorname{Pd}_{2}(\mathrm{dba})_{3}$ and heating in dimethylacetamide (DMA) ${ }^{[12]}$ forced the cyclization and led to the desired 7-membered ring carbamate 9a in reasonable yield as a $E / Z$ mixture of isomers (Table 3 , Conditions $\mathrm{B}$, entry 2$)$. Addition of $\mathrm{P}(o \text {-Tol })_{3}(60 \mathrm{~mol} \%)$ to the previous conditions had a dramatic effect, ${ }^{[13]}$ leading to the same carbamate 9a but in a $94 \%$ yield as a single $Z$-isomer (Table 3 , Conditions $C$, entry 3 ). When these conditions were applied to $\mathbf{8 b}$, the same observations were made and better yield and selectivities were obtained using the combination $\mathrm{Pd}_{2}(\mathrm{dba})_{3} / \mathrm{P}(o-\mathrm{Tol})_{3} / \mathrm{NEt}_{3}$ in DMA (entry 5).

Table 3. Heck reaction on iodoarylamines 8a-b.<smiles>[R]CCC(/C=C/SOc1ccccc1)N(CCc1cc(OC)c(OC)cc1I)C(=O)O</smiles><smiles></smiles>

$8 \mathrm{a}, \mathrm{R}=\mathrm{CO}_{2} \mathrm{Et}$

$\mathbf{8 b}, \mathrm{R}=\mathrm{COMe}$<smiles>[R]CCC1/C(=C\C(=O)Oc2ccccc2)c2cc(OC)c(OC)cc2CCN1C(=O)OCc1ccccc1</smiles>

9a, $\mathrm{R}=\mathrm{CO}_{2} \mathrm{Et}$

9b, $R=$ COMe<smiles>[R]CC/C(=C/C[SH](=O)(O)c1ccccc1)N(CCc1cc(OC)c(OC)cc1I)C(=O)OC</smiles> 


\begin{tabular}{llccll}
\hline $\begin{array}{l}\text { Entr } \\
\mathrm{y}\end{array}$ & $\begin{array}{l}\mathrm{A} \\
\mathrm{rI}\end{array}$ & $\begin{array}{c}\text { Condition } \\
\mathrm{s}^{[\mathrm{a}]}\end{array}$ & $\begin{array}{l}\text { Produc } \\
\mathrm{t}\end{array}$ & $\begin{array}{l}\mathrm{E} / \mathrm{Z} \\
\text { ratio }\end{array}$ & $\begin{array}{l}\text { Yield } \\
(\%)^{[\mathrm{b}]}\end{array}$ \\
\hline 1 & $\mathbf{8}$ & $\mathrm{A}$ & $\mathbf{1 0}$ & $2: 1$ & 82 \\
& $\mathbf{a}$ & & & & \\
2 & $\mathbf{8}$ & $\mathrm{B}$ & $\mathbf{9 a}$ & $1: 1$ & 65 \\
& $\mathbf{a}$ & & & & \\
3 & $\mathbf{8}$ & $\mathrm{C}$ & $\mathbf{9 a}$ & $1: 0$ & 94 \\
& $\mathbf{a}$ & & & & \\
4 & $\mathbf{8}$ & $\mathrm{B}$ & $\mathbf{9 b}$ & $7: 3$ & 70 \\
& $\mathbf{b}$ & & & & \\
5 & $\mathbf{8}$ & $\mathrm{C}$ & $\mathbf{9 b}$ & $1: 0$ & 89 \\
& $\mathbf{b}$ & & & & \\
\hline
\end{tabular}

[a] Cond. A: $\mathrm{Pd}(\mathrm{OAc})_{2}(15 \mathrm{~mol} \%), \mathrm{PPh}_{3}(60 \mathrm{~mol} \%), \mathrm{NEt}_{3}$ (3 eq), DBU (1.5 eq), PhMe then $70{ }^{\circ} \mathrm{C}, 3 \mathrm{~h}$; Cond. B: $\mathrm{Pd}_{2}(\mathrm{dba})_{3}(15 \mathrm{~mol} \%), \mathrm{NEt}_{3}(3 \mathrm{eq}) \mathrm{DMA}, 140{ }^{\circ} \mathrm{C}, 2 \mathrm{~h}$; Cond. C: $\mathrm{Pd}_{2}(\mathrm{dba})_{3}(15 \mathrm{~mol} \%), \mathrm{P}(o-\mathrm{Tol})_{3}(60 \mathrm{~mol} \%)$ $\mathrm{NEt}_{3}$ (3 eq), PhMe, $110{ }^{\circ} \mathrm{C}, 2$ h. ${ }^{[\mathrm{b}]}$ Isolated yields.

Removal of the Boc protecting group in 9a led to the corresponding amine which was not isolated, but directly treated with camphorsulfonic acid in toluene to provide, in high overall yield, the lactam 11, possessing the tricyclic structure of hainanensine (Figure 1). ${ }^{[7 \mathrm{~b}, 14]}$ The structure and stereochemistry of $\mathbf{1 1}$ was unambiguously assigned through X-ray diffraction studies. The stereochemistry of $\mathbf{9 b}$ was assigned accordingly (Scheme 3).

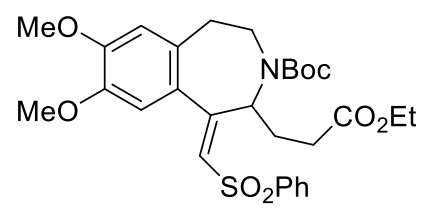

9a

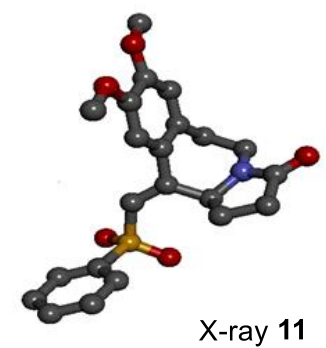

1. TFA, $\mathrm{CH}_{2} \mathrm{Cl}_{2}$

$20^{\circ} \mathrm{C}, 1 \mathrm{~h}$

2. CSA, PhMe

$110^{\circ} \mathrm{C}, 2 \mathrm{~h}$

$1194 \%$ (2 steps)

Scheme 3. Deprotection and lactamization of 9a.

The isomerization of the vinylic 8a into the allylic sulfone $\mathbf{1 0}$ could easily be carried out by treatment with DBU, ${ }^{[15]}$ which led us examine the behavior of $\mathbf{1 0}$ under the above Heck reaction conditions. Treatment of $\mathbf{1 0}$ under conditions $\mathrm{C}$ led to no reaction, likely as a result of the important steric hindrance around the olefinic moiety. However, when conditions B, without ligand, were tested, 10 was converted, in good yield, into a 8:2 mixture of cyclized products 12a and 12b (Scheme 4). These compounds result from a 6-exo Heck cyclization, ${ }^{[16]} \alpha$ - to nitrogen, which delivers the corresponding alkyl-Pd species, undergoing a $\beta$-hydride elimination to form predominantly tetrahydroisoquinoline 12a. A low amount of $\mathbf{1 2 b}$ was also formed resulting from the competitive elimination of the sulfonyl group. ${ }^{[17]}$ The structure of $\mathbf{1 2 b}$ was confirmed through X-ray diffraction studies, while that of $\mathbf{1 2 a}$, was secured after removal of the Boc group and subsequent lactamization under acidic conditions, leading to $\mathbf{1 3}$ in excellent overall yield. 


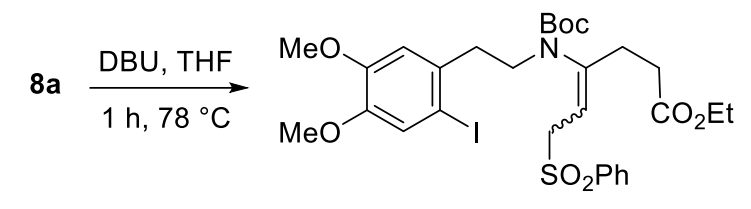

$1096 \%, E / Z(77 / 33)$

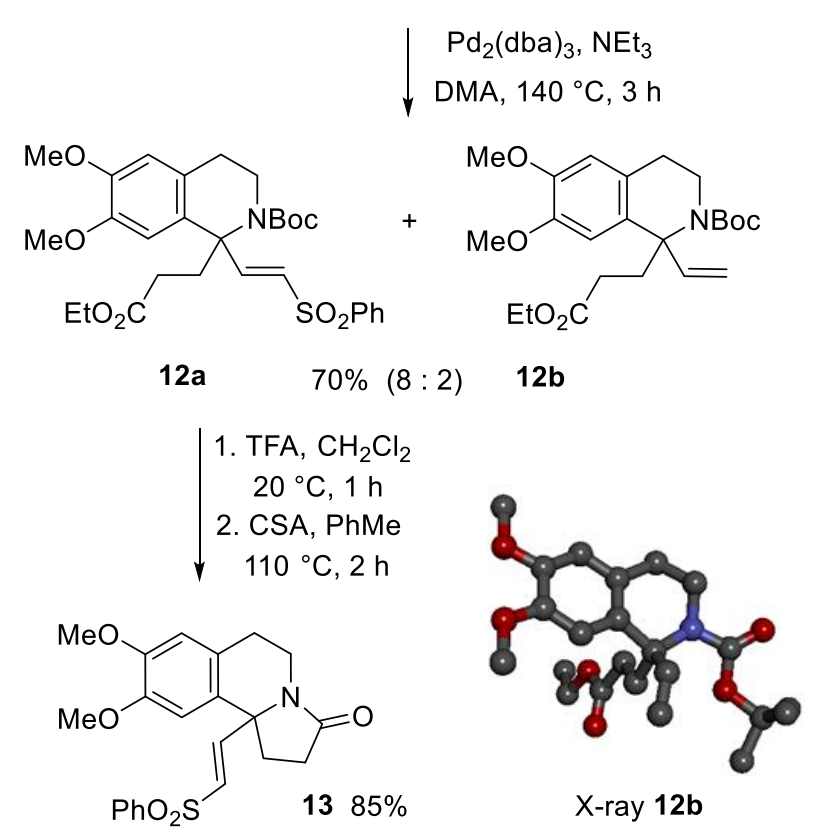

Scheme 4. Heck reaction on iodoaryl-ene-carbamate 10.

The isoquinoline 6-membered ring may also be accessible directly starting from the iodoaryl benzylamine, as shown for 8c (Scheme 5). Treatment of the latter, under conditions B, thus led to the formation of the 6-membered ring system 14. The latter may be formed through a 6-exo Heck cyclization, followed by the isomerization of the cyclization product. Isomerization of $\mathbf{8 c}$ in the basic medium prior to a 6-endo Heck reaction might also be invoked and has some precedent in the literature. ${ }^{[18]}$ However, when $\mathbf{8 c}$ was first isomerized into the ene-carbamate $\mathbf{1 5}$, then cyclized under conditions $\mathrm{B}$, the corresponding isoindolines $\mathbf{1 6 \mathbf { a }}$ and $\mathbf{1 6 \mathbf { b }}$ were formed in reasonable yields instead of 14, thus ruling out the alternative isomerization/6-endo process. This also establishes that the 5-exo Heck cyclization is possible, ${ }^{[19]}$ even with sterically hindered ene-carbamate such as $\mathbf{1 5}$. As above, desulfonylation also occurred in small amount to produce 16b. A 6-exo reaction was also observed with aryl bromide $\mathbf{7 j}$, leading to $\mathbf{1 6} \mathbf{c}$ as a single $Z$-isomer using conditions $\mathrm{C}$ (Scheme 5). Removal of the N-Boc group and lactamization afforded tricyclic 16d in good overall yield and only 4 steps from the corresponding enamide. NOESY experiments (supporting information) establish the Zconfiguration of the vinylsulfone moiety in $\mathbf{1 6 d}$ as well as in its precursor $16 \mathbf{c}$, in good agreement with observations made during the transformation of 8a into Z-9a (Table 3) 
<smiles>COc1cc(I)c(CN(C(=O)OCc2ccccc2)C(/C=C/SO)CCC#N)cc1OC</smiles>
$\mid \begin{aligned} & \mathrm{DBU}, \mathrm{THF} \\ & 16 \mathrm{~h}, 78^{\circ} \mathrm{C}\end{aligned}$

$15,90 \%(E / Z: 63 / 37)$

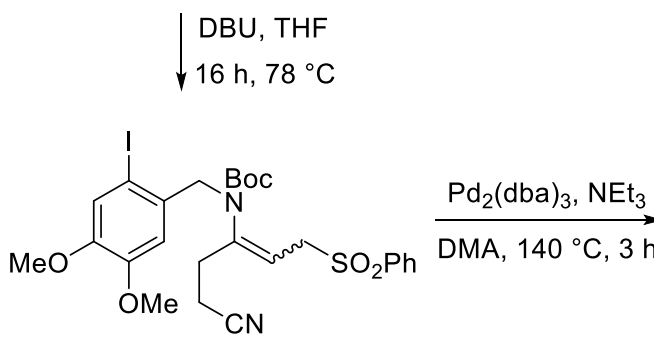

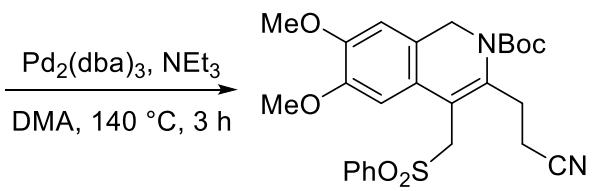

$14,59 \%$<smiles>[R]C=C[C@@]1(CCC#N)c2cc(OC)c(OC)cc2CN1C(=O)OCc1ccccc1</smiles>

16a, $\mathrm{R}=\mathrm{SO}_{2} \mathrm{Ph}(47 \%, E / Z: 55 / 46)$ $+16 b, R=H(13 \%)$

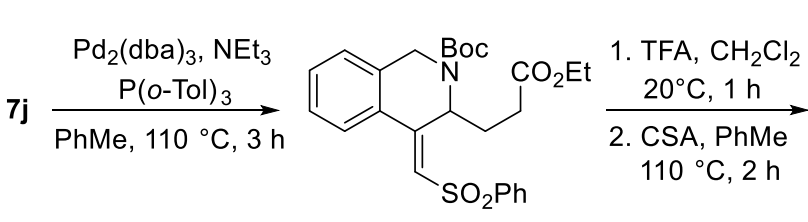

$16 c, 83 \%$ $(Z / E>95: 5)$<smiles>O=C1CCC2/C(=C\S(=O)(=O)c3ccccc3)c3ccccc3CN12</smiles>

$16 d, 64 \%$ $(Z / E>95: 5)$

Scheme 5. Heck reaction on bromo- and iodoarylbenzylamine $\mathbf{7 j}$ and $\mathbf{8 c}$.

The 5-exo Heck cyclization was then extended to iodoarylamines 8e-f, using again conditions B. As described for the analogue $\mathbf{8 c}$, the cyclization was effective, leading directly to the fully substituted indole products after isomerization of the intermediate formed upon cyclization (Scheme 6). Under conditions $\mathrm{B}$, the Heck cyclization is thus followed by an isomerization and the removal of the Boc protecting group to give $17 \mathbf{a}^{[20]}$ Under milder conditions $\left(110^{\circ} \mathrm{C}\right.$ instead of $\left.140^{\circ} \mathrm{C}\right), \mathbf{8 f}$ led to the Bocprotected indole $\mathbf{1 7 b}$ in excellent yield. Bromide $\mathbf{7 f}$ was reactive under conditions $\mathrm{C}$ (with a phosphine) and led to a mixture of the protected and unprotected indoles 18a and $\mathbf{1 8 b}$ in good overall yield. This sequence thus provides a straightforward access to functionalized indoles in only two or three steps starting from simple ene-carbamates.<smiles>[R]CCc1[nH]c2cc(OC)c(OC)c(OC)c2c1CS(=O)(=O)c1ccccc1</smiles>

$$
\begin{array}{ll}
\mathbf{8 e}, \mathrm{R}=\mathrm{CN} & \mathrm{T}=140^{\circ} \mathrm{C} \quad \mathbf{1 7 a}, \mathrm{R}=\mathrm{CN}, \mathrm{R}^{\prime}=\mathrm{H} \quad 61 \% \\
\mathbf{8 f}, \mathrm{R}=\mathrm{CO}_{2} \mathrm{Et} & \mathrm{T}=110^{\circ} \mathrm{C} \quad \mathbf{1 7 b}, \mathrm{R}=\mathrm{CO}_{2} \mathrm{Et}, \mathrm{R}^{\prime}=\mathrm{Boc} \quad 89 \%
\end{array}
$$

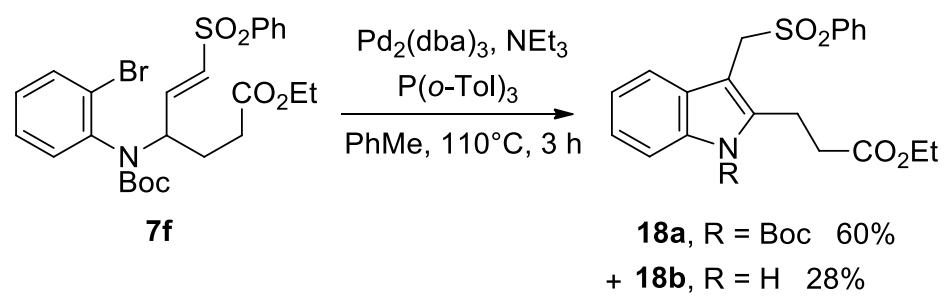

Scheme 6. An access to the indole skeleton through Heck reaction on haloarylamines $\mathbf{7 f}$ and $\mathbf{8 e - f}$. 
As shown above, the free-radical olefin carbo-alkenylation-Heck cyclization sequence provides a straightforward entry to a variety of 5-, 6- and 7-membered nitrogen heterocycles in generally good yields. The carbo-alkenylation of olefins also allows the incorporation of a second functional group, which might be useful for further functionalization, including cascade processes. It was thus anticipated that iodides 8a-f might be involved in a double cyclization, resulting from the addition of an aryl-metal onto the unsaturated sulfone, followed by a second cyclization on the ester or nitrile of the side chain (Scheme 7).

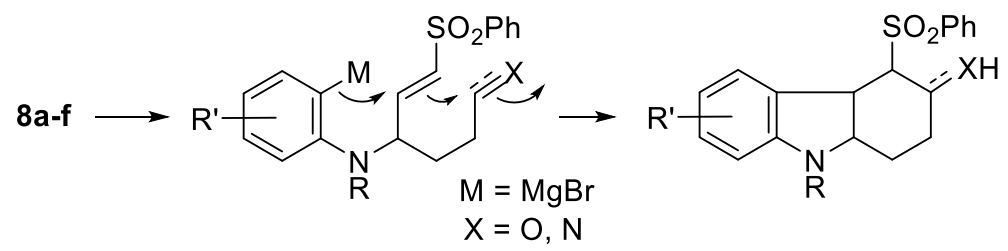

Scheme 7. Nucleophilic cascade processes as a route to hydrocarbazoles.

Preliminary attempts were carried out starting from aryl iodide 8f. A Grignard reagent was thus generated from the latter using Knochel reagent ${ }^{[21]}(i-\mathrm{PrMgCl}-\mathrm{LiCl}$ in THF), then transmetallation of the organomagnesium intermediate with a stoichiometric amount of $\mathrm{CuCN}$ (Table 4, entry 1). Two cyclized products 19 and 20 were thus formed; i.e. a keto-sulfone 19 resulting from the expected double cyclization depicted in Scheme 7, and a second tricyclic system 20, likely formed through further reduction of $\mathbf{1 9}$ under the reaction conditions. Each compound was formed as a single diastereomer, with stereochemistry as shown. A second experiment (entry 2), without the addition of the copper salt, afforded the same products in a similar ratio, showing that the Grignard reagent alone was adding to the vinyl sulfone and that the resulting $\alpha$-sulfonyl carbanion was reactive enough to add to the ester group. ${ }^{[2]}$ Several conditions were then tested to decrease the amount of alcohol formed during the process. Adding $i$-PrMgCl-LiCl slowly, using a syringe pump (entry 3 ), slightly improved the ratio in favor of the ketone 19. Changing the solvent from THF to benzene did not modify the ratio (entry 4), in contrast with earlier work suggesting that when benzene was used as a solvent, the reduction by $i$-PrMgCl-LiCl could be minimized. ${ }^{[23]}$ Finally transmetallation with $\mathrm{ZnCl}_{2}$ led to the same results (entry 5). ${ }^{[24]}$ Interestingly, monitoring of the reaction mixture (TLC analysis) after $1 \mathrm{~h}$ at $-90^{\circ} \mathrm{C}$ showed that, even at this low temperature, formation of the Grignard reagent and the double cyclization were occurring and were faster than the transmetallation.

Table 4. Anionic cascade using $i-\mathrm{PrMgCl}-\mathrm{LiCl}$ reagent.
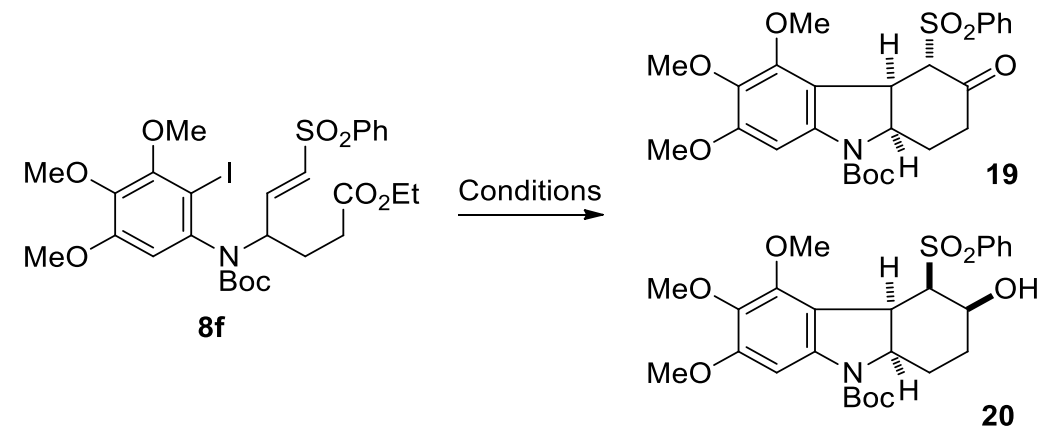


\begin{tabular}{|c|c|c|c|}
\hline $\begin{array}{l}\text { Entr } \\
\mathrm{y}\end{array}$ & Conditions & $\begin{array}{c}\text { Yield } \\
19 \\
(\%)^{[\mathrm{f}, \mathrm{g}]}\end{array}$ & $\begin{array}{c}\text { Yield } \\
\mathbf{2 0} \\
(\%)^{[\mathrm{f}, \mathrm{g}]}\end{array}$ \\
\hline 1 & $\begin{array}{l}i \text {-PrMgCl-LiCl, } \mathrm{CuCN} \\
\text { [a] }\end{array}$ & 37 & 37 \\
\hline 2 & $i-\operatorname{PrMgCl}-\mathrm{LiCl}^{[\mathrm{b}]}$ & 30 & 30 \\
\hline 3 & $\begin{array}{l}i \text {-PrMgCl-LiCl, Cond } \\
\mathrm{A}^{[\mathrm{c}]}\end{array}$ & 52 & 20 \\
\hline 4 & $\begin{array}{l}i \text {-PrMgCl-LiCl, Cond B } \\
\text { [d] }\end{array}$ & 48 & 27 \\
\hline 5 & $i$-PrMgCl-LiCl, $\mathrm{ZnCl}_{2}{ }^{[\mathrm{e}]}$ & 51 & 22 \\
\hline
\end{tabular}

[a] $i$-PrMgCl-LiCl (2 equiv.), THF, $6.5 \mathrm{~h}$ at $0^{\circ} \mathrm{C}$ then $\mathrm{RT}, 12 \mathrm{~h}$, then $\mathrm{CuCN}-2 \mathrm{LiCl}\left(1.2\right.$ equiv.), $-25^{\circ} \mathrm{C}, 2.5 \mathrm{~h}$. ${ }^{\text {[b] }}$ $i$-PrMgCl- $\mathrm{LiCl}$ (2.8 equiv.), THF, $6.5 \mathrm{~h}$ at $-40^{\circ} \mathrm{C}$. ${ }^{[\mathrm{c}]} \mathrm{Cond}$. A: $i$-PrMgCl- $\mathrm{LiCl}$ (2.8 equiv.) added with a syringe pump over $12 \mathrm{~h}$, THF, $0^{\circ} \mathrm{C}$. ${ }^{[d]}$ Cond. B: $i$-PrMgCl-LiCl (4.8 equiv.) added with a syringe pump over $12 \mathrm{~h}$, benzene, RT. ${ }^{[e]}$ Cond. C: $i$-PrMgCl- $\mathrm{LiCl}$ (3.8 equiv.), THF, $-90^{\circ} \mathrm{C}$, then $\mathrm{ZnCl}_{2}$, THF, $-90^{\circ} \mathrm{C}$, to RT, 4 h. ${ }^{[\mathrm{f}]}$ Isolated yields after chromatography. ${ }^{[\mathrm{g}]} \mathbf{1 9}$ and 20 were obtained as single diastereoisomers (supporting information).

Treatment of the ketone 19 with $i$-PrMgCl-LiCl led to the alcohol 20 in $47 \%$ yield with complete diastereocontrol, along with $43 \%$ of the recovered starting material, thus demonstrating that $\mathbf{2 0}$ was formed through reduction of $\mathbf{1 9}$ with the excess of $i$-PrMgCl-LiCl (Scheme 8). 19 was also reduced more efficiently with $\mathrm{NaBH}_{4}$ affording 20 in high yield and complete diastereocontrol.

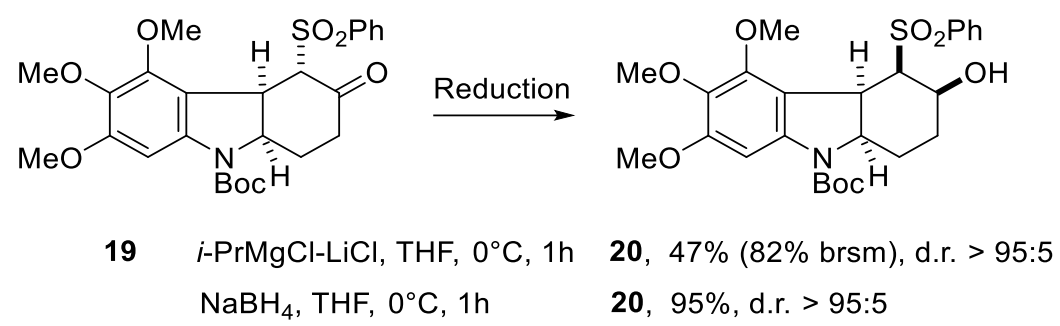

Scheme 8. Reduction of ketone 19.

The stereochemistry of $\mathbf{1 9}$ and that of the reduced product 20, assigned through ${ }^{1} \mathrm{H}$ NMR studies (for extensive NMR experiments, see supporting information), indicates that epimerization at the chiral center bearing the sulfonyl group has occurred. This isomerization likely took place prior to the reduction, as enolization of the $\alpha$-sulfonylketone 19 into its epimer 19' (which has not been isolated) (Scheme 9) should be relatively easy under the reaction conditions, considering the acidity of the proton $\alpha$ - to the carbonyl group (pka ranging between 11-15 in DMSO). ${ }^{[22,25]}$ DFT calculations showed that 19 and 19' display lowest energy twist-boat conformations, with energy difference (computed at the M06-2X/6-31G(d,p) level) of $3.5 \mathrm{kcal} / \mathrm{mol}$. Closer examination of these conformations however revealed that axial and equatorial approaches of the reductive agent onto the carbonyl group of $\mathbf{1 9}$ are both hindered, while the equatorial position is more easily accessible in the least stable 19', rationalizing the stereochemical outcome. ${ }^{[26]}$ The strong interaction between the $\mathrm{PhSO}_{2}$ moiety and the ortho-OMe substituent of the aromatic substituent in 19' explains its higher energy as compared to $\mathbf{1 9}$. The reduction of $\mathbf{1 9}$ thus proceeds under a Curtin-Hammett regime, through the least stable, but more reactive epimer 19'. It is finally worth noticing that when alcohol 20 was oxidized using Dess-Martin periodinane, ketone 19 was obtained in $78 \%$ yield as a single isomer. Oxidation of $\mathbf{2 0}$ likely provides first the ketone isomer 19', which then epimerizes into the thermodynamically more stable epimer 19. 

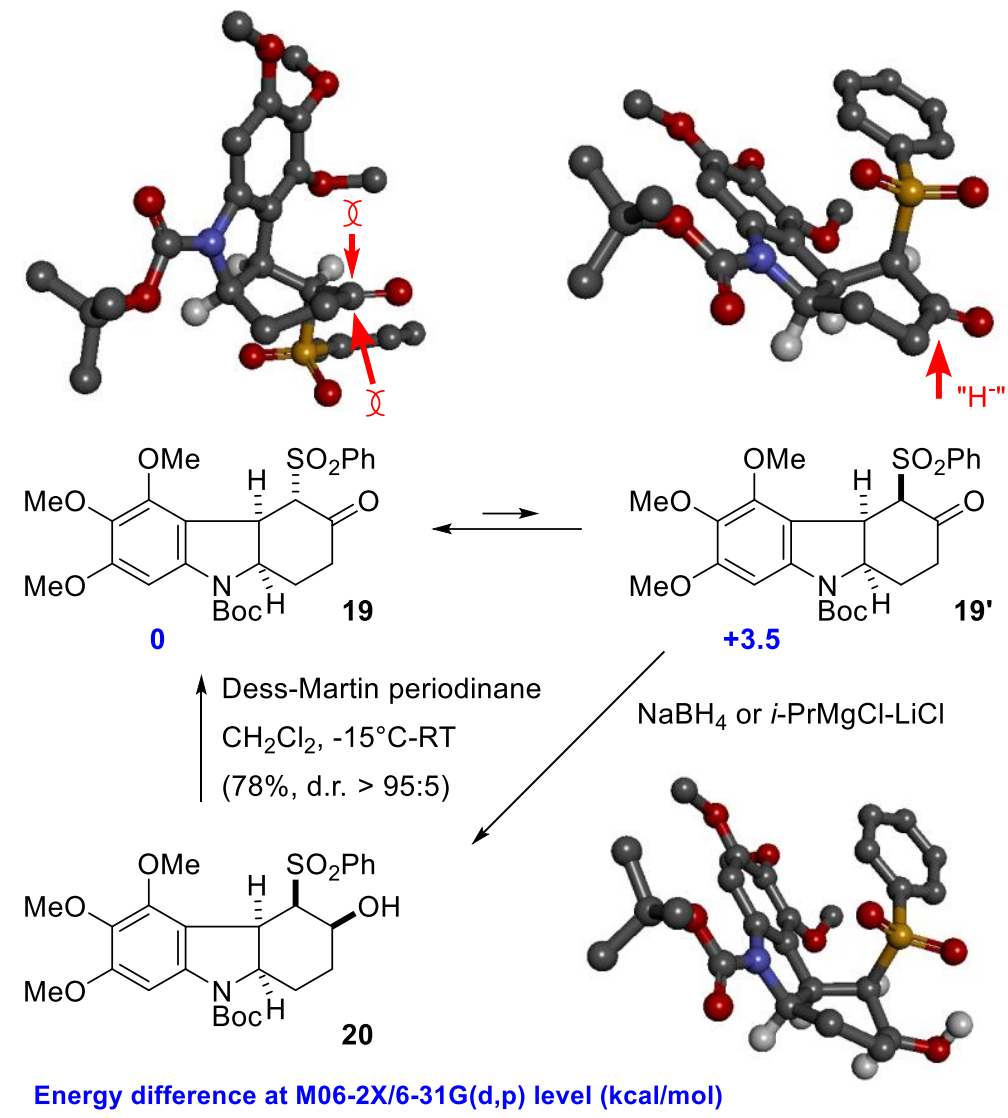

Scheme 9. Epimerization and computed models for the reduction of ketone 19.

The double anionic cyclization cascade was then extended to nitrile $\mathbf{8 e}$ (Scheme 10). This led to a tricyclic product 21, obtained as a single cis-isomer, and exhibiting an enamine function resulting from the tautomerization of the $\alpha$-sulfonylimine product.<smiles>CCCCN(C(=O)OCc1ccccc1)c1cc(OC)c(OC)c(OC)c1I</smiles>

$8 \mathbf{e}$<smiles>COc1cc2c(c(OC)c1OC)[C@H]1C(S(=O)(=O)Oc3ccccc3)=C(N)CC[C@@H]21</smiles>

21, $54 \%$, d.r. $>95: 5$

Scheme 10. Double anionic cyclization of nitrile $8 \mathbf{e}$.

Finally, the strategy was applied to the cyclization of cyclic enamide $\mathbf{2 4}$, easily obtained through the free-radical carbo-olefination of enamide 22, followed by the iodination of the resulting threecomponent adduct 23 (Scheme 11). Iodoaryl-enamide 24 was thus treated with $i$-PrMgCl-LiCl under above conditions, leading to the expected tetracyclic product $\mathbf{2 5}$, as a single isomer, albeit in poor yield. No trace of the ketone precursor was detected under such conditions. The poor yield is probably due to the important strain and the trans-stereochemistry in precursor 24, which disfavors the successive cyclizations. The structure of $\mathbf{2 5}$ was unambiguously established through ${ }^{1} \mathrm{H}$ NMR studies (Supporting information). Although the yield of the cyclization step is low, the unusual structure of $\mathbf{2 5}$ is noteworthy, with 3 stereogenic centers created in a single pot. 


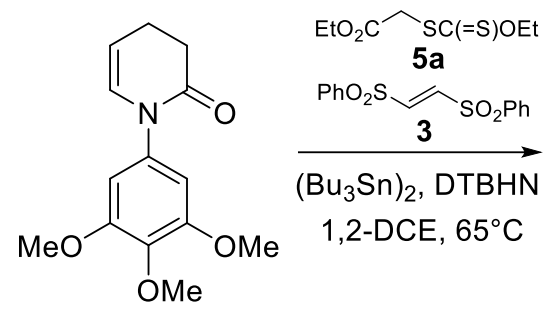

22

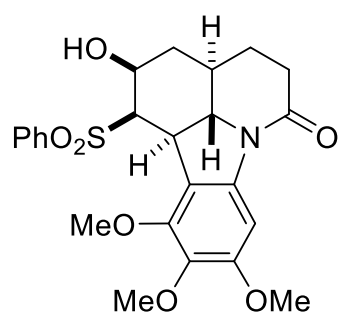

$25(17 \%$, d.r. $>95: 5)$

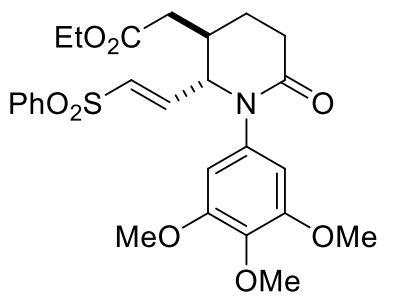

$23(76 \%$ d.r. $>95: 5)$

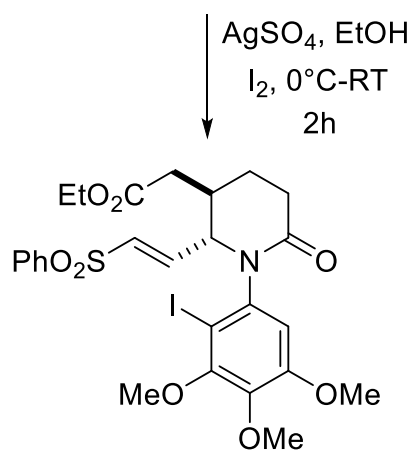

$24(82 \%$, d.r. > 95:5)

Scheme 11. Double anionic cyclization of enamide 24.

\section{Conclusion}

In summary, we reported here on the straightforward access to a series of nitrogen heterocycles through a sequence of 3 consecutive reactions, including a free-radical olefin carbo-alkenylation, followed by a regioselective iodination of an arene, and finally an organometallic-mediated cyclization. Intramolecular Heck reaction and anionic (Grignard) processes were used to close the ring and generate the heterocycles. 5-, 6 and 7-membered rings are thus accessible through this sequence, offering an efficient and unified access to precursors of various alkaloids (Figure 1). ${ }^{[7,27]}$ The initial carbo-alkenylation of olefins may also be performed on compounds bearing an aryl bromide, thus allowing the elaboration into a given heterocycle in only 2 steps (7j and $\mathbf{7 f}$, scheme 5-6). The use of the Knochel "turbo Grignard" reagent led to double anionic cyclization affording polycyclic systems in generally good yields and high stereocontrol. Interestingly, further stereoselective reduction of the resulting ketone was also observed under these conditions. Finally, it is worth adding that an access to enantioenriched 5- and 6-membered heterocycles is at hand starting from precursors $\mathbf{1 0}$ or $\mathbf{1 5}$ using $\mathrm{Pd}$ catalysts and chiral ligands. Work along these lines is currently under progress and will be reported in due course. 


\section{Experimental Section}

General procedure A for the Free-radical carbo-alkenylation of ene-carbamates.

To a solution of xanthate 5a (1 equiv.) in dry 1,2-DCE ( 2.5 to $15 \mathrm{~mL}$ ) were added ene-carbamate 6 (1 to 2 equiv.), vinyldisulfone 3 (1.2 equiv.) and di(tributyltin) (1 to 1.5 equiv.). The reaction mixture was degassed, then $15 \mathrm{~mol} \%$ of DTBHN were added and the reaction mixture was stirred for $1.5 \mathrm{~h}$ at $65^{\circ} \mathrm{C}$. The yellow reaction mixture was then concentrated under reduced pressure and purified by chromatography on silica gel (Petroleum ether (PE)/EtOAc).

(E)-Ethyl 4-((3,4-dimethoxyphenethyl) (methoxycarbonyl)amino)-6-(phenylsulfonyl) hex-5-enoate (7a). Synthesized according to general procedure A, from ethyl xanthate $\mathbf{5 a}(143 \mathrm{mg}, 0.687 \mathrm{mmol}, 1$ equiv.), ene-carbamate $\mathbf{6 a}$ (365 mg, $1.38 \mathrm{mmol}, 2$ equiv.), E-1,2-Bis(phenylsulfonyl)ethylene 3 ( $254 \mathrm{mg}, 0.83 \mathrm{mmol}, 1.2$ equiv.) and di(tributyltin) (400 $\mu \mathrm{L}, 0.75 \mathrm{mmol}, 1.1$ equiv.) in 1,2-DCE ( $3 \mathrm{~mL}$ ). Purification by flash chromatography (PE/EtOAc 70:30 to 50:50) afforded 7a (314 mg, 88\%) as a pale yellow oil. $\mathbf{R}_{\mathbf{f}}=0.28(\mathrm{PE} / \mathrm{EtOAc} 70 / 30) ; \mathbf{I R}(\mathrm{ATR}) v_{\max }\left(\mathrm{cm}^{-1}\right)=1727,1695,1515$, 1446, 1260, 1144, 1025, 755; ${ }^{1} \mathbf{H}-\mathbf{N M R}\left(300 \mathrm{MHz}, \mathrm{CDCl}_{3}\right) \delta(\mathrm{ppm})=7.89-7.79(\mathrm{~m}, 2 \mathrm{H}), 7.65-7.46(\mathrm{~m}, 3 \mathrm{H}), 7.04-6.85$ (m, 1H), 6.80-6.75 (m, 1H), 6.71-6.59 (m, 2H), $6.38(\mathrm{~d}, J=15.0 \mathrm{~Hz}, 1 \mathrm{H}), 4.82-4.42(\mathrm{~m}, 1 \mathrm{H}), 4.09(\mathrm{q}, J=7.2 \mathrm{~Hz}, 2 \mathrm{H})$, $3.86(\mathrm{~s}, 3 \mathrm{H}), 3.84(\mathrm{~s}, 3 \mathrm{H}), 3.77-3.59(\mathrm{~m}, 3 \mathrm{H}), 3.35-3.14(\mathrm{~m}, 2 \mathrm{H}), 2.87-2.64(\mathrm{~m}, 2 \mathrm{H}), 2.37-2.21(\mathrm{~m}, 2 \mathrm{H}), 2.08-1.88(\mathrm{~m}$, $2 \mathrm{H}), 1.21(\mathrm{t}, J=7.2 \mathrm{~Hz}, 3 \mathrm{H}) ;{ }^{13} \mathbf{C}-\mathbf{N M R}\left(75 \mathrm{MHz}, \mathrm{CDCl}_{3}\right) \delta(\mathrm{ppm})=172.4,156.6,149.0,147.7,144.1,139.9,133.6$, 132.2, 131.0, 129.4, 127.7, 120.7, 111.9, 111.4, 60.7, 56.2, 55.9, 52.9, 46.9, 36.1, 30.4, 26.4, 14.2; HRMS (ESI) Calcd. for $\mathrm{C}_{26} \mathrm{H}_{33} \mathrm{NO}_{8} \mathrm{NaS}[\mathrm{M}+\mathrm{Na}]^{+} 542.1819$, found 542.1819.

\section{General procedure $\mathbf{C}$ for the Heck reaction.}

To a stirred solution of iodoarylamines 8 (1 equiv.), (o-tol $)_{3} \mathrm{P}$ (conditions $\mathrm{C}$ ) and $\mathrm{Pd}_{2}(\mathrm{dba})_{3}$ (0.15 equiv.) in toluene (conditions $\mathrm{C}$ ) or DMA (conditions $\mathrm{B}$ ) were added $\mathrm{Et}_{3} \mathrm{~N}$ ( 3 equiv.) at room temperature and the resulting mixture was stirred under reflux for $2 \mathrm{~h}$. The reaction mixture was quenched with saturated $\mathrm{NH}_{4} \mathrm{Cl}$ aq. and partitioned between $\mathrm{CH}_{2} \mathrm{Cl}_{2}$ and water. The organic phase was collected and the aqueous phase extracted with $\mathrm{CH}_{2} \mathrm{Cl}_{2}(2 \times 30 \mathrm{~mL})$. The combined organic extract was dried over $\mathrm{Na}_{2} \mathrm{SO}_{4}$, filtered and concentrated in vacuo. The residue was purified by flash chromatography on silica gel (EP/EtOAc) to afford the desired compound.

(Z)-Tert-butyl

2-(3-ethoxy-3-oxopropyl)-7,8-dimethoxy-1-((phenylsulfonyl)methylene)-4,5-dihydro-1Hbenzo[d]azepine-3(2H)-carboxylate (9a). Synthesized according to general procedure $\mathrm{C}$ (conditions $\mathrm{C}$ ) from iodide $\mathbf{8 a}$ (2.1 g, 3.06 mmol, 1 equiv.) in PhMe (30 mL), (o-tol) 3 P (558.1 mg, $1.836 \mathrm{mmol}, 0.6$ equiv.), $\mathrm{Pd}_{2}(\mathrm{dba})_{3}(420.3 \mathrm{mg}, 0.459$ mmol, 0.15 equiv.) and $\mathrm{Et}_{3} \mathrm{~N}(1.29 \mathrm{~mL}, 9.18 \mathrm{mmol}, 3$ equiv.). Purification by flash chromatography on silica gel, (70/30 to $60 / 40 \mathrm{PE} / \mathrm{EtOAc})$ afforded compound $9 \mathrm{a}(1.601 \mathrm{~g}, 94 \%)$ as a yellow oil.

$\mathbf{R}_{\mathbf{f}}=0.23$ (PE/AcOEt 60/40); IR (ATR) $v_{\max }\left(\mathrm{cm}^{-1}\right)=2972,1729,1694,1514,1446,1264,1143,1082,731 ;{ }^{1} \mathbf{H}-\mathbf{N M R}$ $\left(400 \mathrm{MHz}, \mathrm{CDCl}_{3}\right) \delta(\mathrm{ppm})=8.05-7.92(\mathrm{~m}, 2 \mathrm{H}), 7.61-7.46(\mathrm{~m}, 3 \mathrm{H}), 6.59(\mathrm{~s}, 1 \mathrm{H}), 6.57(\mathrm{~s}, 1 \mathrm{H}), 6.38(\mathrm{~s}, 1 \mathrm{H}), 6.33(\mathrm{t}, J=$ $7.2 \mathrm{~Hz}, 1 \mathrm{H}), 4.05(\mathrm{q}, J=7.2 \mathrm{~Hz}, 2 \mathrm{H}), 3.82(\mathrm{~s}, 3 \mathrm{H}), 3.79(\mathrm{~s}, 3 \mathrm{H}), 3.74-3.64(\mathrm{~m}, 1 \mathrm{H}), 3.55-3.41(\mathrm{~m}, 1 \mathrm{H}), 2.86-2.73(\mathrm{~m}, 2 \mathrm{H})$, 2.28-2.18 (m, 2H), 2.11-2.00 (m, 1H), 1.78-1.67 (m, 1H), $1.48(\mathrm{~s}, 9 \mathrm{H}), 1.20(\mathrm{t}, J=7.2 \mathrm{~Hz}, 3 \mathrm{H}) ;{ }^{13} \mathbf{C}-\mathbf{N M R}(100 \mathrm{MHz}$, $\left.\mathrm{CDCl}_{3}\right) \delta(\mathrm{ppm})=172.6,156.3,155.1,150.7,148.2,142.2,133.4,132.0,131.5,129.3,127.6,114.7,113.4,80.8,60.4$, 56.7, 56.2, 52.1, 41.5, 36.0, 31.1, 28.5, 28.0, 14.2; HRMS (ESI) Calcd. for $\mathrm{C}_{29} \mathrm{H}_{37} \mathrm{NO}_{8} \mathrm{NaS}[\mathrm{M}+\mathrm{Na}]^{+} 582.2288$ found 582.2286.

\section{General procedure D for anionic cascade using Knochel Grignard reagent.}

To a solution of iodide ( 1 equiv.) in THF was added dropwise, using a syringe pump, a $1.18 \mathrm{M}$ solution of $i$-PrMgCl-LiCl in $\operatorname{THF}\left(1.3\right.$ to 4 equiv.) at $0^{\circ} \mathrm{C}$. The yellow reaction mixture was stirred $1-2 \mathrm{~h}$ at $0^{\circ} \mathrm{C}$, then $1-2 \mathrm{~h}$ at room temperature and finally quenched with an aqueous ammonium chloride solution. The aqueous layer was extracted with EtOAc. The combined organic layers were washed with brine, dried over sodium sulfate and concentrated under reduced pressure. The crude mixture, after purification by column chromatography (silica gel), gave tricyclic ketones and corresponding alcohols.

Ketone (19) and alcohol (20). Synthesized according to general procedure D from iodide 8e (205.7 mg, $0.30 \mathrm{mmol}, 1$ equiv.) in THF ( $3 \mathrm{~mL})$ and $1.18 \mathrm{M}$ solution of $i-\mathrm{PrMgCl}-\mathrm{LiCl}$ in THF $(0.56 \mathrm{~mL}, 0.66 \mathrm{mmol}, 2.2$ equiv.) added via syringe pump for $12 \mathrm{~h}$ at $0^{\circ} \mathrm{C}$. Purification by flash chromatography on silica gel (PE/EtOAc 80/20 to 72/18) afforded the ketone 19 (80.3 mg, 52\%, d.r. > 95:5) as a colorless oil and alcohol $\mathbf{2 0}(31.4 \mathrm{mg}, 20 \%$, d.r. > 95:5) as a white solid.

(4S,4aR,9aR)-Tert-butyl 5,6,7-trimethoxy-3-oxo-4-(phenylsulfonyl)-2,3,4,4a-tetrahydro-1H-carbazole-9(9aH)carboxylate (19). $\mathbf{R}_{\mathbf{f}}=0.44(\mathrm{PE} / \mathrm{EtOAc} 70 / 30)$; IR (ATR) $v_{\max }\left(\mathrm{cm}^{-1}\right)=2969,1701,1604,1484,1394,1323,1168 ;{ }^{1} \mathbf{H}-$ 
NMR $\left(600 \mathrm{MHz}, 328.2 \mathrm{~K}, \mathrm{CDCl}_{3}\right) \delta(\mathrm{ppm})=7.97-7.93(\mathrm{~m}, 2 \mathrm{H}), 7.71-7.67(\mathrm{~m}, 1 \mathrm{H}), 7.63-7.58(\mathrm{~m}, 2 \mathrm{H}), 7.24(\mathrm{brs}, 1 \mathrm{H})$, 4.98-4.90 (m, 2H), $4.71(\mathrm{~d}, J=10.0 \mathrm{~Hz}, 1 \mathrm{H}), 3.84(\mathrm{~s}, 3 \mathrm{H}), 3.72(\mathrm{~s}, 3 \mathrm{H}), 3.71(\mathrm{~s}, 3 \mathrm{H}), 2.74(\mathrm{ddt}, J=15.1 \mathrm{~Hz}, J=13.7 \mathrm{~Hz}$ and $J=4.2 \mathrm{~Hz}, 1 \mathrm{H}), 2.55(\mathrm{dt}, J=17.8 \mathrm{~Hz}$ and $J=4.1 \mathrm{~Hz}, 1 \mathrm{H}), 2.40-2.33(\mathrm{~m}, 1 \mathrm{H}), 2.21(\mathrm{ddd}, J=18.0 \mathrm{~Hz}, J=13.6 \mathrm{~Hz}$ and $J=4.5 \mathrm{~Hz}, 1 \mathrm{H}), 1.59(\mathrm{~s}, 9 \mathrm{H}) ;{ }^{13} \mathbf{C}-\mathbf{N M R}\left(50 \mathrm{MHz}, \mathrm{CDCl}_{3}\right) \delta(\mathrm{ppm})=200.7,154.8,152.1,149.7,139.5,139.2,137.3$, $134.3,129.5,128.5,111.5,95.8,81.8,71.8,61.2,60.7,56.6,56.2,38.2,34.7,28.6,24.8$; HRMS (ESI) Calcd. for $\mathrm{C}_{26} \mathrm{H}_{31} \mathrm{NO}_{8} \mathrm{NaS}[\mathrm{M}+\mathrm{Na}]^{+} 540.1668$ found 540.1665 .

(3S,4R,4aR,9aR)-Tert-butyl 3-hydroxy-5,6,7-trimethoxy-4-(phenylsulfonyl)-2,3,4,4a-tetrahydro-1H-carbazole9(9aH)-carboxylate (20). $\mathbf{R}_{\mathbf{f}}=0.22(\mathrm{PE} / \mathrm{EtOAc} 70 / 30) ; \mathbf{M p}=120^{\circ} \mathrm{C}(\mathrm{PE} / \mathrm{EtOAc}) ; \mathbf{I R}(\mathrm{ATR}) v_{\max }\left(\mathrm{cm}^{-1}\right)=3497,2974$, 1699, 1596, 1478, 1332, 1146, 914; ${ }^{1} \mathbf{H}-\mathbf{N M R}\left(300 \mathrm{MHz}, \mathrm{CDCl}_{3}\right) \delta(\mathrm{ppm})=8.10-7.99(\mathrm{~m}, 2 \mathrm{H}), 7.74-7.55(\mathrm{~m}, 3 \mathrm{H}), 7.43-$ 7.10 (brs, $1 \mathrm{H}), 4.94$ (d, $J=4.0 \mathrm{~Hz}, 1 \mathrm{H}), 4.85-4.66(\mathrm{~m}, 1 \mathrm{H}), 4.46-4.16$ (brs, $1 \mathrm{H}), 4.08-3.93(\mathrm{~m}, 1 \mathrm{H}), 3.89$ (d, $J=7.9 \mathrm{~Hz}$, $1 \mathrm{H}), 3.82(\mathrm{~s}, 3 \mathrm{H}), 3.70(\mathrm{~s}, 3 \mathrm{H}), 3.37(\mathrm{~s}, 3 \mathrm{H}), 2.53-2.37(\mathrm{~m}, 1 \mathrm{H}), 2.30(\mathrm{dq}, J=3.8 \mathrm{~Hz}$ and $J=13.0 \mathrm{~Hz}, 1 \mathrm{H}), 1.98-1.83(\mathrm{~m}$, 1H), 1.62-1.37 (m, 10H); ${ }^{13} \mathbf{C}-\mathbf{N M R}\left(50 \mathrm{MHz}, \mathrm{CDCl}_{3}\right) \delta(\mathrm{ppm})=154.1,151.8,150.5,139.9,137.6,137.2,134.1,129.5$, 128.2, 111.3, 96.7, 81.2, 70.1, 64.3, $61.0,60.2$, 57.1, 56.2, 41.0, 28.5, 28.0, 27.6; HRMS (ESI) Calcd. for $\mathrm{C}_{26} \mathrm{H}_{33} \mathrm{NO}_{8} \mathrm{NaS}$ $[\mathrm{M}+\mathrm{Na}]^{+} 542.1825$ found 542.1821 .

\section{References}

[1] a) J. R. Lewis, Nat. Prod. Rep. 2001, 18, 95; b) D. O’ Hagen, Nat. Prod. Rep. 2000, 17, 435; b) P. S. Watson, B. Jiang and B. Scott, Org. Lett. 2000, 2, 3679; c) T. Gogfraid, R. Miller, M. Wibo, Pharmacol. Rev. 1986, 38, 32; d) Y.-F. Chang, C.-W. Guo, T.-H. Chan, Y.-W. Pan, E.-L. Tsou, W.-C. Cheng, Mol. Div. 2011, 15, 203.

[2] a) M. Baumann, I. R. Baxendale, Beilstein J. Org. Chem. 2013, 9, 2265; b) M. Baumann, I. R. Baxendale, S. V. Ley, N. Nikbin, Beilstein J. Org. Chem. 2011, 7, 442.

[3] For selected examples, see: a) A. J. Clark, Chem. Soc. Rev. 2002, 31, 1; b) R. Bowman, A. J. Fletcher, G. B. S. Potts, J. Chem. Soc., Perkin Trans. 1, 2002, 2747 and references cited herein; c) M. T. Barros, A. M. F. Phillips, Heterocycl. Targets Adv. Org. Synth. 2011, 1; d) P.-Q. Huang, Asym. Synth. Nitrogen Heterocycl. 2009, 51; e) N. Kaur, J. Dwivedi, D. Kishore, Synth. Commun. 2014, 44, 1671; f) N. Kaur, D. Kishore, Synth. Commun. 2014, 44, 1173; g) K. C. Majumdar, P. K. Basu, P. P. Mukhopadhyay, Tetrahedron 2005, 61, 10603; h) K. C. Majumdar, P. Debnath, N. De, B. Roy, Curr. Org. Chem. 2011, 15, 1760; i) K. C. Majumdar, G. V. Karunakar, B. Sinha, Synthesis 2012, 44, 2475; j) P. Majumdar, A. Pati, M. Patra, R. K. Behera, A. K. Behera, Chem. Rev. 2014, 114, 2942; k) P. Matyus, P. Tapolcsanyi, Asym. Synth. Nitrogen Heterocycl. 2009, 293; 1) K. Mollet, M. D'Hooghe, N. De Kimpe, Mini-Rev. Org. Chem. 2013, 10, 1; m) C. J. Moody, Chem. Commun. 2004, 1341; n) P. Somfai, J. Ahman, Targets Heterocycl. Syst. 1999, 3, 341; o) Y. Troin, M.-E. Sinibaldi, Asym. Synth. Nitrogen Heterocycl. 2009, 139; p) Y.-J. Wu, B. V. Yang, Prog. Heterocycl. Chem. 2013, 25, 257; q) H.-P. Husson, J. Royer, Chem. Soc. Rev. 1999, 28, 383; r) J. L. Vicario, D. Badia, L. Carrillo, N. Ruiz, E. Reyes, Targets Heterocycl. Syst. 2008, 12, 302; s) Z. Amara, J. Caron, D. Joseph, Nat. Prod. Rep. 2013, 30, 121.

[4] a) U. Bothe, H. C. Rudbeck, D. Tanner, M. Johannsen, J. Chem. Soc., Perkin Trans. 1, 2001, 3305; b) Y. K. Kim, T. Livinghouse, Angew. Chem., Int. Ed. 2002, 41, 3645; Angew. Chem. 2002, 114, 3797; c) S. R. Fix, J. L. Brice, S. S. Stahl, Angew. Chem., Int. Ed. 2002, 41, 164; Angew. Chem. 2002, 114, 172; d) J.-S. Ryu, T. J. Marks, F. E. McDonald, Org. Lett. 2001, 3, 3091; e) I. Dragutan, V. Dragutan, C. Mitan, H. C. M. Vosloo, L. Delaude, A. Demonceau, Beilstein J. Org. Chem. 2011, 7, 699; f) F.-X. Felpin, J. Lebreton, Eur. J. Org. Chem. 2003, 3693.

[5] a) A. D. Jones, D. W. Knight, D. E. Hibbs, J. Chem. Soc., Perkin Trans. 1, 2001, 1182; b) W. S. Lee, K. C. Jang, J. H. Kim, K. H. Park, Chem. Commun. 1999, 251; c) Y. Tamaru, S. Kawamura, T. Bando, K. Tanaka, M. Hojo, Z. Yoshida, J. Org. Chem. 1988, 53, 5491; d) Z. Shao, J. Chen, Y. Tu, L. Li, H. Zhang, Chem. Commun. 2003, 1918.

[6] a) L. D. Miranda, S. Z. Zard, Org. Lett. 2002, 4, 1135; b) C. Kalaï, E. Tate, S. Z. Zard, Chem. Commun. 2002, 1430; c) L. Chabaud, Y. Landais, P. Renaud, Org. Lett. 2005, 7, 2587.

[7] a) S. N. Gaskell, L. J. Duffy, S. M. Allin, Nat. Prod. Comm. 2008, 3, 1825 and references cited therein; b) Z.-W. Zhang, W.-D. Z. Li, Org. Lett. 2010, 12, 1649; c) J. M. Lopchuk, Prog. Het. Chem. 2011, $23,1$.

[8] a) E. Godineau, Y. Landais, J. Am. Chem. Soc. 2007, 129, 12662; b) V. Liautard, F. Robert, Y. Landais, Org. Lett. 2011, 13, 2658; c) C. Poittevin, V. Liautard, R. Beniazza, F. Robert, Y. Landais, Org. Lett. 2013, 15, 2814; d) B. Ovadia, F. Robert, Y. Landais, Org. Lett. 2015, 17, 1958; e) Y. Landais, F. Robert, E. Godineau, L. Huet, N. Likhite, Tetrahedron 2013, 69, 10073; f) B. Ovadia, F. Robert, Y. Landais, Chimia 2016, 70, 34; g) R. Beniazza, V. Liautard, C. Poittevin, B. Ovadia, S. Mohammed, F. Robert, Y. Landais, Chem. Eur. J. 2017, 23, 2439; h) H. Hassan, V. Pirenne, M. Wissing, K. Chahinaz, A. Hussain, F. Robert, Y. Landais, Chem. Eur. J. 2017, 23, 4651. 
[9] a) W.-W. Sy, B. A. Lodge, A.W. By, Synth. Commun. 1990, 20, 877; b) W.-W. Sy, Synth. Commun. 1992, 22, 3215; c) S. Wing-Wah, Tetrahedron Lett. 1993, 34, 6223.

[10] For general reviews on Heck reaction, see: a) A. de Meijere, F. E. Meyer, Angew. Chem. Int. Ed. 1994, 33, 2379; Angew. Chem. 1994, 106, 2473; b) I. Beletskaya, A. Cheprakov, Chem. Rev. 2000, 100, 3009; For selected examples of the utilization of the Heck reaction in the synthesis of heterocycles, see: c) L. F. Tietze, H. Schirok, M. Wohrmann, Chem. Eur. J. 2000, 6, 510; d) R. Grigg, V. Santhakumar, V. Sridharan, P. Stevenson, A. Teasdale, M. Thornton-Pett, T. Worakun, Tetrahedron 1991, 47, 9703; e) G. Zeni, R. Larock, Chem. Rev. 2006, 106, 4644; f) P. J. Guiry, D. Kiely, Current Org. Chem. 2004, 8, 781.

[11] J. P. Michael, C. B. Koning, T. T. Mudzunga, R. L. Petersen, Synlett 2006, 19, 3284.

[12] Q. Liu, E. M. Ferreira, B. M. Stoltz, J. Org. Chem. 2007, 72, 7352.

[13] K. Kitahara, S. Atsushi, J. Himokawa, T. Fukuyama, Chem. Sci. 2014, 5, 904.

[14] L. F. Tietze, R. Schimpf, Synthesis 1993, 876.

[15] a) S. K. Guha, Y. Ukaji, K. Inomata, Chem. Lett. 2003, 1158; b) K. Inomata, S. Sasaoka, T. Kobayashi, Y. Tanaka, S. Igarashi, T. Ohtani, H. Kinoshita, H. Kotake, Bull. Chem. Soc. Jpn. 1987, 60, 1767; c) T. Kobayashi, Y. Tanaka, T. Ohtani, H. Kinoshita, K. Inomata, H. Kotake, Chem. Lett. 1987, 1209; d) K. Inomata, T. Hirata, H. Suhara, H. Kinoshita, H. Kotake, H. Senda, Chem. Lett. 1988, 2009.

[16] a) Y. Ban, T. Wakamatsu, M. Mori, Heterocycles 1977, 6, 1711; b) J. H. Rigby, R. C. Hughes, M. J. Heeg, J. Am. Chem. Soc. 1995, 117, 7834.

[17] T. Cuvigny, C. Hervé du Penhoat, M. Julia, Tetrahedron 1987, 43, 859.

[18] a) J. W. Dankwardt, L. A. Flippin, J. Org. Chem. 1995, 60, 2312; b) S. Berteina, A. De Mesmaeker, Synlett 1998, 1227; c) S. Berteina, S. Wendeborn, A. De Mesmaeker, Synlett 1998, 1231; d) S. Lemaire-Audoire, M. Savignac, C. Dupuis, J.-P. Genet, Tetrahedron Lett. 1996, 37, 2003.

[19] a) A. Kasahara, T. Izumi, S. Murakami, H. Yanai, Bull. Chem. Soc. Jpn. 1986, 59, 927; b) R. C. Larock, S. Babu, Tetrahedron Lett. 1987, 28, 5291; c) M. M. Abelman, T. Oh, L. E. Overman, J. Org. Chem. 1987, 52, 4130.

[20] a) R. Odle, B. Blevins, M. Ratcliff, L. S. Hegedus, J. Org. Chem. 1980, 45, 2709; b) L. S. Hegedus, T. A. Mulhern, A. Mori, J. Org. Chem. 1985, 50, 4282.

[21] a) P. Knochel, W. Dohle, N. Gommermann, F. F. Kneisel, F. Kopp, T. Korn, I. Sapountzis, V. Ahn Vu, Angew. Chem., Int. Ed. 2003, 42, 4302; Angew. Chem. 2003, 115, 4438; b) A. Krasovskiy, P. Knochel, Angew. Chem., Int. Ed. 2004, 43, 3333; Angew. Chem. 2004, 116, 3396; c) H. Ren, A. Krasovskiy, P. Knochel, Org. Lett. 2004, 6, 4215; d) F. Kopp, A. Krasovskiy, P. Knochel, Chem. Commun. 2004, 2288.

[22] N. S. Simpkins, Sulphones in Organic Synthesis, in Tetrahedron Organic Chemistry Series, Eds J. E. Baldwin, P. D. Magnus, Pergamon Press, Oxford, 1993, Vol 10.

[23] P. Canonne, G. Foscolos, H. Caron, G. Lemay, Tetrahedron 1982, 38, 3563.

[24] M. Hatano, S. Suzuki, K. Ishihara, J. Am. Chem. Soc. 2006, 128, 9998.

[25] F. G. Bordwell, J. E. Bares, J. E. Bartmess, G. E. Drucker, J. Gerhold, G. J. McCollum, M. Van Der Puy, N. R. Vanier, W. S. Matthews, J. Org. Chem. 1977, 42, 326 and references cited therein.

[26] a) W. G. Dauben, G. J. Fonken, D. S. Noyce, J. Am. Chem. Soc. 1956, 78, 2579; b) D. C. Wigfield, Tetrahedron 1979, 35, 449 .

[27] M. Kawano, T. Kiuchi, S. Negishi, H. Tanaka, T. Hoshikawa, J.-i. Matsuo, Angew. Chem. Int. Ed. 2013, 52, 906; Angew. Chem. 2013, 125, 940. 